\title{
AN UNUSUAL PRESENTATION OF OBSESSIVE COMPULSIVE DISORDER (OCD) - A CASE REPORT
}

T. Hemchand Singh ${ }^{1}$, H. Nirendrakumar Singh ${ }^{2}$, Y. Rameshware Singh ${ }^{3}$

\section{HOW TO CITE THIS ARTICLE:}

T. Hemchand Singh, H. Nirendrakumar Singh, Y. Rameshware Singh. "An Unusual Presentation of Obsessive Compulsive Disorder (OCD) - A Case Report". Journal of Evolution of Medical and Dental Sciences 2014; Vol. 3, Issue 07, February 17; Page: 1567-1568, DOI: 10.14260/jemds/2014/2025

INTRODUCTION: A 48 years old male married Hindu; assistant agriculture officer from Imphal attended Psychiatric OPD with the chief complaints of repeated checking of his house and its premise, repeated washing of hands, feet and clothes and injecting tetanus toxoid almost every day for duration of five years. The patient was apparently alright 5 years back when he gradually started suspecting that there may be snake in or around his house; so he started checking inside and premises of his house repeatedly before going to bed. This had become a daily routine and so excessive that the cells of his torch wouldn't last for more than 3-4 days. He also started washing his hands and feet excessively; be it before his meal or returning from toilet in fear of contamination with germs. He would also wash his clothes everyday taking a lot of time; so much that washing and cleaning took nearly 2-3 hrs. every day. Preparing for office became a lengthy ritual that most of the time he was late for office. After returning from office; he washed his feet for more than 1 hour; using boiled water.

Then he sprinkled water on the way to his room and then put on socks to prevent contamination. He would not allow his family members to come inside the room before completing the above procedure. During the latter part of his illness; that is for last 4 yrs.; he had become extremely preoccupied and terrified of having tetanus infections. After any minor injury, scratch or even without any cuts or pricks; he had to inject himself tetanus toxoid or else he felt very restless. During this period he had been self-injecting tetanus toxoid almost every day. Although frequency of injection has markedly reduced during last two years after treatment. All this behavior became so uncontrollable, bothersome and excessive; which markedly impaired his personal, social and occupational life. So finally he came to Psychiatry OPD RIMS. Family history was significant as one of his cousin brothers had died of tetanus 10yrs back.

Mental status examination showed patient was anxious and restless. He was preoccupied with thoughts of contamination and getting infected with tetanus. His cognitive function was not impaired and insight was Grade V. Physical examination detected no abnormalities. Routine laboratory investigations were within normal limits. Diagnosis of OCD was made by DSM-IV-TR criteria.

The patient was managed with combined pharmacotherapy and psychotherapy. Pharmacotherapy - Fluoxetine 60mg orally daily in the morning, Clonazepam $(0.5 \mathrm{mg})$ twice daily; which was gradually tapered off after 3 months; Psychotherapy - Cognitive-Behavioral Therapy: exposure and response prevention, relaxation technique and supportive psychotherapy. With ongoing treatment, the patient has significantly improved in his social, interpersonal and occupational functioning.

According to Yale-Brown Obsessive Compulsive Scale the pretreatment score of the patient was found to be 31 and the post treatment score was found to be 16 which showed that the patient 
had improved significantly in his daily activities. Patient was found to be asymptomatic up to 6 months when he last came for checkup.

DISCUSSION: The essential feature of OCD is the symptoms of recurrent obsessions or compulsions sufficiently severe to cause marked distress to the persons. The obsessions or compulsion are time consuming and interfere significantly with the person's activities. OCD affects Male and Female adult equally. OCD usually have onset before 25 years but less than $15 \%$ have onset after the age of 35.1 The onset of symptoms for about 50-70\% of patients occurs after stressful live events such as dead of a relative. ${ }^{2}$ Family studies of patients have shown that 35\% of first degree relatives of OCD patients are also afflicted with the disorder. ${ }^{3}$ Pharmacotherapy such as SSRI (Fluoxetine and Fluvoxamine) is very effective in the management of OCD. ${ }^{4,5}$ Psychotherapy such as cognitive behavior therapy in the form of exposure and response prevention found to be very effective ${ }^{6}$. But combined pharmacotherapy and psychotherapy is the treatment of choice in the management of OCD ${ }^{7}$.

\section{REFERENCES:}

1. Black DW, Noyes R, Goldstein RB, Blum N. A family study of obsessive compulsive disorder. Achieve Journal of Psychiatry. 1992. 49:362.

2. Albert U, Maina G, Bogetto. Obsessive Compulsive Disorder (OCD) and triggering life events. European Journal Psychiatry. 2000.14(3):180.

3. Wolff M. Alsobrook JP, Pauls DL. Genetic aspects of obsessive compulsive disorder. Psychiatry Clinical North America. 2000.23(3):535.

4. Hollander E, Kaplan A, Allen A. Cartwright C. Pharmacotherapy for obsessive compulsive disorder. Psychiatry Clinical North America. 2000. 23(3): 643.

5. Fineberg NA, Bullock T, Montgomery DB, Montgomery SA. Serotonin reuptake inhibitors are the treatment of choice in obsessive compulsive disorder. Internal Clinical Psychopharmacology. 1992.7(suppl.1):43.

6. Neziroglu F, Hsia C, Yaryura JA. Behavioral, cognitive and family therapy for obsessive compulsive and related disorder. Psychiatry Clinical North America 2000.23(3):657.

7. Mathew SJ, Simpson HB, Fallon BA. Treatment strategies for obsessive compulsive disorder. Psychiatry Ann. 2000. 30(11):699.

\section{AUTHORS:}

1. T. Hemchand Singh

2. H. Nirendrakumar Singh

3. Y. Rameshware Singh

\section{PARTICULARS OF CONTRIBUTORS:}

1. Assistant Professor, Department of Psychiatry, JNIMS Porompat, Imphal.

2. Assistant Professor, Department of Community Medicine, JNIMS Porompat, Imphal.

3. Assistant Professor, Department of Paediatrics, JNIMS Porompat, Imphal.

\author{
NAME ADDRESS EMAIL ID OF THE \\ CORRESPONDING AUTHOR: \\ Dr. T. Hemchand Singh, \\ Psychiatrist, Keishampat, \\ Kangajam Leikai, Imphal, \\ Manipur - 795001. \\ E-mail: hnirendra10@gmail.com
}

Date of Submission: 21/01/2014. Date of Peer Review: 22/01/2014. Date of Acceptance: 28/01/2014. Date of Publishing: 11/02/2014. 